\title{
Jornalismo
}

\section{"Um soberbo mostruário de atrações": a vivência da rua na crônica urbana do Diário de Notícias (1925-1930)}

"A superb showcase of attractions": street life experience in Diário de Notícias (1925-1930)

\section{LUCIANA MURARI}

Professora Doutora do Programa de Pós-Graduação em Letras, Cultura e Regionalidade da Universidade de Caxias do Sul (UCS), Caxias do Sul, RS, Brasil. Bolsista de Produtividade em Pesquisa (CNPq).

<lmurari@hotmail.com>

\section{RESUMO}

Este artigo analisa a representação da sociabilidade de Porto Alegre, entre 1925 e 1930, por meio das crônicas publicadas na coluna diária $A$ Cidade, do jornal Diário de Notícias. São apresentadas as percepções do autor, Roque Callage, em relação ao que era vivido no espaço da rua, relacionadas à observação da cena urbana, ao convívio interpessoal, ao esporte, ao lazer e à vida cultural. Temos como objetivo acompanhar a forma como a experiência da cidade era textualizada e significada pela imprensa.

Palavras-chave: Imprensa. Sociabilidade. Porto Alegre.

\section{ABSTRACT}

The present essay analyses the representation of sociability in Porto Alegre between 1925 and 1930 through the daily column A Cidade published in the Diário de Notícias. The perceptions of its author, Roque Callage, are presented in relation to street life daily experiences - observation of the urban scene, interpersonal interaction, sports, leisure activities and cultural life. The study aims to characterize how city life was textualized and signified by the press.

Keywords: Press. Sociability. Porto Alegre. 
- $\mathrm{n}$ tre março de 1925 e dezembro de 1930, Roque Callage assinou a coluna A Cidade, $\triangle$ no Diário de Notícias de Porto Alegre ${ }^{1}$. Atuante desde muito jovem no jornalismo, o titular da coluna havia se notabilizado no meio cultural sul-rio-grandense como autor de ensaios e contos de temática regionalista. Naquele espaço de jornal, contudo, ele se tornaria o que parecia ser o antípoda de sua militância cultural nativista: um entusiasta da remodelação urbana, da atualização produtiva, da sincronização da capital com as grandes metrópoles, não apenas no que diz respeito aos aspectos imediatos da ocupação e da organização do espaço, mas também dos comportamentos, sociabilidades e práticas cotidianas. Este artigo investe na discussão deste aspecto: a representação, pela crônica de Callage, de novas formas de experimentar a cidade, a partir da transformação dos hábitos de lazer e das formas de convívio nos espaços públicos.

O aparente paradoxo rural-urbano que caracteriza a carreira do escritor não é, entretanto, difícil de compreender, se pensamos que o regionalismo é, por essência, uma manifestação romântica de rememoração das raízes rurais, típica de contextos da modernização produtiva. Em que pese seu espírito nostálgico, esta atitude não implica na rejeição da modernidade e, pelo contrário, participa da implantação da percepção de ruptura histórica e da criação das identidades sociais modernas. Conto regional e crônica urbana correspondem, assim, à forma literária desta aparente antinomia que caracteriza a obra de Callage. A narrativa do conto regional é uma forma reminiscente da difusão oral da experiência. Por isto, escreve Walter Benjamin, as melhores histórias escritas são as que mais se parecem com as contadas por narradores anônimos que comunicam a experiência: conselhos, ensinamentos, normas (Benjamin, 2012).

Por outro lado, a crônica vincula-se à difusão da imprensa, linguagem por excelência da criação das nações modernas, "comunidades imaginadas" que se nutrem da partilha, cotidiana e anônima, do texto impresso (Anderson, 2008). A crônica 
jornalística, prendendo-se à experiência imediata, renuncia à exemplaridade e ao ensinamento moral. Sua matéria não é, decerto, o duradouro, mas a efemeridade do vivido, os movimentos do acaso, os sentimentos e sensações alimentados pela multiplicidade de estímulos da vida urbana. Compreendemos, assim, que Callage assimile a cidade, espaço vivido, à sua coluna $A$ Cidade, espaço escrito, que converte Porto Alegre em um texto a ser lido cotidianamente, a partir dos recortes aleatórios do cronista, fragmentos de uma vivência tão individual quanto coletiva, tão única quanto repetitiva: "Com outra queda violenta de temperatura, vai à cama o resto da cidade, inclusive esta 'Cidade', que anda também vai não vai..." (Diário de Notícias, 16 jul. 1927)2.

Anunciando um dos períodos em que o cronista titular licenciou-se do Diário de Notícias, seu inominado substituto provisório afirmou que este teria adquirido tal intimidade com os "segredos da urbe que se moderniza", que a coluna poderia ser considerada seu diário de viagem. Isto porque o temperamento errático do escritor teria se disciplinado para limitar sua peregrinação incessante ao espaço da cidade:

Nômade por instinto, ele educou e subordinou o seu erraticismo nos limites da cidade. Dentro dela, viaja incessantemente, como se viajasse o próprio planeta. E as impressões dessa contínua peregrinação ele as escreve aqui - pequeno "diário" de um homem que sempre se considera itinerante, ainda quando se senta para trabalhar. E a propósito: viajando, de verdade, metido num carro da Viação Férrea, o Callage não se sentiu - estamos a apostá-lo - muito bem. O carro era-lhe uma forçada imobilidade. De que lhe valia o trem a correr, se ele estava parado?"

(07 fev. 1928) 
A ideia da errância remete-nos ao imaginário do flâneur, o homem que, despreocupadamente, caminha pela cidade, observando as pessoas em suas tarefas cotidianas e buscando no simplório o extraordinário, capaz de definir uma estética renovada, moderna por excelência. Segundo Walter Benjamin, ele é o personagem paradigmático da modernidade urbana, convertendo a cidade, dividida em suas contradições, em uma paisagem ilimitada que se expande diante de si, mas que ao mesmo tempo o envolve como um quarto, capaz de resguardar a individualidade do observador, e de mantê-lo fora do alcance, encerrado em sua própria inquietação. Assim, a cidade contém, para o flâneur, também as dimensões da intimidade e da familiaridade, que fazem com que ele se aproprie do espaço urbano como se fosse sua própria casa. Ele exercita, em sua caminhada errática, o antigo sonho do labirinto, revelando, naquilo que parece próximo, o que pode haver de mais exótico (Benjamin, 2009, pp. 462-474).

A crônica de Callage contém alguns dos atributos essenciais da flânerie: a sensação de movimento, impressa pela forma descontínua, fragmentária e heterogênea, como os aspectos diversos da cidade sucedem-se no cotidiano da coluna; a busca da beleza no prosaico do cotidiano; o sentido de introspecção impresso pela familiaridade com o ambiente urbano. E, ao mesmo tempo, o jornalismo é, ainda de acordo com Benjamin, a base social da flânerie, uma vez que, através da imprensa, o homem de letras colocase no mercado, onde a literatura será inscrita nos circuitos da produção capitalista. Como flâneur, o jornalista é um estudioso da cidade e de seus tipos e, nos momentos em que vaga pelas avenidas, acumula o "tempo socialmente necessário" 3 à produção de sua força de trabalho (Marx apud Benjamin, 2009, p. 490). Isto porque o valor dela é ampliado pelo ócio incorporado à escrita e apresentado ao público como algo que adquire mais valor do que o próprio trabalho, e, que pode ser compreendido a partir da perspectiva do aprofundamento da experiência dos lugares próximos, 
paralela à generalização e à uniformização da experiência moderna (Benjamin, 2009, p. 487-497).

\section{O espetáculo da rua}

Nas crônicas de Callage, o espaço de encontro por excelência é a própria rua. Em Porto Alegre, a mais célebre delas era a Rua da Praia, que não se resumia ao footing em torno do comércio prestigioso. Pelo contrário, ela era uma demonstração da diversidade do espaço urbano, abrigando não apenas o que a cidade tinha de mais esnobe, como também os mendicantes - deficientes físicos, leprosos, crianças, autênticos dependentes da caridade pública ou não - e um imprevisível freak-show, exibição de aberrações físicas humanas e animais que desafiavam a credibilidade pública: "as raridades fenomenais, principalmente, não encontram melhor ponto do que ela para porem em prática as explorações rendosas de suas deformidades físicas e morais" (24 abr. 1925).

Não por acaso, ainda que as cenas narradas pela crônica sejam apenas expressão da banalidade cotidiana, a rua é comparada a um caleidoscópio ou a um cosmorama, instrumento ótico que conduzia à observação de vistas de vários países: olhando pela janela em um dia de chuva, o cronista acompanha pessoas sonolentas na hora da sesta, um cão sarnoso, "a figura gesticulante de um camelô escandaloso, trazendo uma enorme víbora enrolada no pescoço", ônibus, automóveis, bondes, um guarda de trânsito (08 jan. 1928). Neste conjunto, destaca-se o basbaque, personagem derrisório em seu deslumbramento em face dos estímulos sensoriais múltiplos do ambiente urbano saturado de "atrações", em que a aparente normalidade apenas se impõe graças à indiferença exercitada pelo homem moderno em relação a eles (Sennet, 1988, p. 368).

Na crônica citada acima, tanto quanto o deslumbrado, o cronista se fixa na figura de uma bela mulher, cujas formas eram devassadas pelo sol de verão. A observação das figuras femininas que se exibiam nas ruas de Porto Alegre era, em si, um espetáculo 
urbano, tema constante de $A$ Cidade. Em alguns momentos de suas crônicas da canícula porto-alegrense, por exemplo, Callage afirma que a tortura do calor na cidade era agravada por vários fatores: o mormaço, a poeira, os mosquitos e o "nu artístico", que submetia os homens a um aumento extra da temperatura (18 nov. 1927; 01 dez. 1929). Na coluna, a expressão "nu artístico" fazia referência à moda feminina em vigor, uma vez que o início de sua publicação, em 1925, coincide com o surgimento de uma verdadeira revolução nos costumes: o encurtamento das saias, que chegaram a cobrir apenas os joelhos. A novidade causou escândalo mundo afora, mas resistiu às proibições da Igreja e do Estado, chegando ao auge em 1927 e decaindo apenas no final da década de 1920. O ideal feminino de beleza era, naquele momento, a silhueta andrógina, o que deu origem a outra grande mudança estética: o uso de cabelos curtos, à la garçonne (Laver, 1989, pp. 230-238).

A primeira aparição do termo "nu artístico", para se referir à moda feminina, surge em uma crônica sobre as exposições de pintura da capital e, a partir daí, o termo se torna recorrente (05 nov. 1925). Juntamente com ele, surge, pouco depois, o "raio X", referência à observação do corpo feminino à contraluz nas tardes de verão, através dos tecidos leves: "É que o sol ali tem a mesma função dos aparelhos de raio X em gabinete de radioscopia..."

(11 nov. 1925). Alguns anos depois destes primeiros registros, $A$ Cidade anotava com certo fastio a rotinização da "nudez".

Mas tão repetidos e frequentes são esses quadros vivos que a cidade apresenta no verão (e até mesmo no inverno) que já ninguém mais olha esbugalhadamente, penetrantemente. É que esses quadros já deixaram de ser uma novidade atraente para se tornarem uma perseguição insistente. O abuso do hábito já não faz a mossa de ninguém."

(18 nov. 1928). 
Ainda assim, a beleza feminina seguia sendo um objeto de exposição, uma vez que a rua tornava-se um espaço preferencial de sociabilidade e um ambiente consagrado para a sedução e o encontro, mesmo distanciado, entre os sexos, através do footing, da frequência aos cinemas, aos cafés, às confeitarias e ao comércio. Mesmo que a "nudez" das silhuetas, cobertas por vestidos fluidos e curtos, tenha sido, afinal, aceita como parte da rotina, a observação da mulher era ainda uma das atrações da cena urbana. A rua - a Rua da Praia, em particular -, era, nos dias ensolarados, um "mostruário agradável de beleza, de graças, de elegâncias", onde as mulheres eram submetidas ao escrutínio dos homens elegantes, que avaliavam o apuro de suas roupas, ou dos "desocupados" que a elas dirigiam seus gracejos (12 ago. 1925; 21 dez. 1928).

O novo padrão estético torna-se tão generalizado que não apenas deixa de impressionar como se torna imperativo, a crer na crônica sempre hiperbólica de Callage. Num primeiro caso, temos a história de uma senhora que tem seu vestuário submetido à censura pública da rua, de forma tão ruidosa que seu marido acaba por recorrer à polícia para queixar-se do embaraço. Segundo o cronista: "Naturalmente, ela andava vestida..." (19 nov. 1925). Outra personagem dá margem a uma crônica jocosa que define uma mulher caminhando pela calçada com um vestido longo como "uma concorrência vantajosa à ineficiente vassoura municipal" (11 jan. 1930). Em uma terceira situação, duas mulheres vão ao footing, pela Rua da Praia, elegantemente trajadas, mas sem meias, deixando as pernas completamente nuas (21 mar. 1926). Nestes casos, o espetáculo não está propriamente na observação da beleza feminina, mas em outro passatempo oferecido pela rua: a maledicência em face da inadequação ou das pequenas subversões da norma, no contexto de uma moralidade ainda muito conservadora.

Além de ser a "mulher-paisagem" submetida ao popular "raio X", através do qual "com mais facilidade devassa o homem, o desconhecido e o mistério", a moda em 
vigor transformava mesmo um ato singelo como a subida das senhoras nos bondes em um acontecimento digno de observação pelo público masculino, por proporcionar uma exposição ainda maior do corpo feminino (22 nov. 1929; 24 jul. 1925). Não espanta que surjam nesta época, como uma novidade, os concursos de miss, que passaram a ser promovidos, a partir de 1929, pelo jornal A Noite, do Rio de Janeiro, representado no Rio Grande do Sul pelo Diário de Notícias (04 jan. 1929).

Da mesma forma, com a ditadura do corte à la garçonne, uma mulher de cabelos longos causa sensação em sua aparição pública, despertando sentimentos contraditórios: embora fosse considerada uma "verdadeira raridade de museu", a beleza da cabeleira, desafiando as imposições da moda, despertava o interesse que os cabelos curtos haviam deixado de atrair. Além disto, a patente indiferença da personagem pela opinião alheia é pintada como um ato heroico, despertando a inveja das mulheres e o desejo dos cabeleireiros. Nítidas metáforas eróticas associam a cabeleira, na crônica, a múltiplos fios embaraçados capazes de enredar e prender corações, e, a uma floresta virgem que despertava o desejo de derrubada pela "volúpia cortante de um machado". Embora a condição da moça torne-se invejável às demais mulheres pelo que tinha de atraente, original e sedutor, o anacronismo impõe-se como a sentença definitiva sobre o episódio: “Enfim, a época passou (...)” (11 jul. 1928). Afinal, como diz o jornalista, os cabelos curtos não eram apenas um fenômeno estético, pois simbolizavam um novo contexto social, em que as mulheres ansiavam por ter ideias, o que, segundo ele, colocava o mundo masculino sob o risco de "graves desordens sociais" (Callage, 01 mar. 1925).

Partindo de sua rua mais famosa, que era tanto a "grande artéria luminosa da futilidade e da graça" quanto "uma artéria insuportável", as crônicas de A Cidade já anunciavam, nos anos 1920, alguns dos problemas urbanos mais graves, como a poluição sonora, os engarrafamentos e os acidentes de trânsito (25 jun. 1925; 26 
ago. 1927). Os "ruídos neurastenizantes" vinham das buzinas dos automóveis, das ambulâncias da Assistência Pública, dos pregões dos camelôs, dos propagandistas de freak-show e vendedores de loterias, dos bondes e carroças, das fábricas que anunciavam o início do expediente, dos vendedores das casas comerciais à cata de clientes, além dos foguetes das festas populares.

A atração da rua era, portanto, inseparável dos excessos que ela reunia, e do desconforto causado, em grande parte, pela precariedade do calçamento na maioria das vias públicas, fazendo com que os passantes tivessem que suportar a lama na época das chuvas e a poeira no estio, além dos buracos e valos que não raro interrompiam o fluxo dos veículos. Na época das chuvas, em particular, não era incomum que o trânsito ficasse inteiramente interrompido nas vias suburbanas, dificultando o acesso à cidade e à circulação dentro dela.

Neste contexto, é compreensível que o cronista considerasse impossível, no final de 1925, a realização da prática do automobilismo, que se difundia em outras capitais, em função da carência de vias com bom calçamento. Situação que se transforma, nos anos seguintes, com a reforma de algumas estradas suburbanas, promovida pela Associação de Estradas de Rodagem (12 dez. 1925). Neste sentido, é com um misto de entusiasmo e ironia que as corridas de automóvel são, posteriormente, recebidas pelo cronista; pois, embora parecessem ser uma novidade, de fato, não se diferenciavam das cenas observadas cotidianamente nas ruas centrais, onde, de acordo com ele, os praticantes do novo esporte vinham fazendo treinamento (11 maio 1927).

Os acidentes de trânsito eram a face trágica da desordem urbana. Embora, para Callage, a gravidade desta situação fosse peculiar a Porto Alegre, a crônica urbana de São Paulo registra uma situação muito similar, como demonstrou Nicolau Sevcenko. O automóvel era um objeto de consumo de luxo, cujo fascínio não residia em sua 
utilidade, mas em sua condição de emblema de superioridade social, o que convidava os condutores a buscarem distinguir-se, seja pela velocidade ou pelo uso constante da buzina. Uma cultura da desigualdade fazia com que nem sequer houvesse punição para os crimes do trânsito, que se tornava um espaço de lazer movido pela emoção do risco - não tanto para os próprios condutores, como para os demais e, principalmente, para os pedestres, "alvos" preferenciais dos automóveis. Segundo o autor, isto demonstrava a permanência da cultura escravocrata, que tendia a afirmar as posições de poder através da prática cotidiana da violência da elite sobre os "subalternos" (Sevcenko, 1992, p. 74). Na rua, espaço democrático por natureza, as desigualdades sociais também se expunham à observação pública.

\section{Cinemas, cafés e música na praça}

Dentre as atividades de lazer popular, a frequência aos cinemas era tão generalizada que se tornava imperativa, "uma obrigação como qualquer outra". Colocando a diversão ao alcance de muitos, o cinema dinamizava vida social. Apesar de existirem cinemas de elite, como o Central, que exigia o uso de gravatas, o cinema era uma diversão popular, acessível mesmo à classe operária (Steyer, 2001, pp. 135-138): “Deixem lá - o cinema é a civilização", define o colunista. Afinal, ele era o responsável pela vivência constante e maciça da rua, em relação a um "antigamente" bastante restrito à vida doméstica, em que o acesso ao lazer era limitado pela inconstância das temporadas musicais, teatrais e circenses. A “onda formidável de povo" que se espalhava pelas vias públicas nos horários mais concorridos representava, enfim, a possibilidade de um intercâmbio social mais amplo, ampliando as perspectivas do encontro e da descoberta (12 ago. 1925). Ao final da década de 1920, Porto Alegre possuía cerca de quinze cinemas, contando, além disto, com salas pertencentes a particulares, clubes, casas de diversão e paróquias, sendo algumas delas localizadas nos bairros, onde se cobravam 
ingressos mais baratos (Steyer, 2001, pp. 70-80). Percebe-se que viver o movimento do cinema não significava apenas fechar-se em suas salas escuras: era também deixar a casa para ir à rua.

O cinema, apesar de sinônimo de civilização, representaria, entretanto, o risco de alienação das mulheres num mundo de sonho e de futilidade, que, na visão do cronista, as afastava de sua real função na sociedade, que ainda se prendia à casa, e, não, à rua (10 out. 1926). Como lembra Beatriz Sarlo, ao estudar a vida cultural de Buenos Aires no mesmo período, o cinema, assim como as revistas, difundia uma nova imagem feminina e instituíam um padrão de comportamento mais aberto no tocante às relações entre os sexos, o que incluía a prática de esportes e a exploração de novos campos de trabalho, por exemplo. No entanto, este "lugar comum do imaginário coletivo", a chamada "mulher moderna", estava ainda muito longe da realidade, mesmo entre as elites intelectuais, que se prendiam a velhos padrões de comportamento (Sarlo, 2010, p. 49-50).

Dentro do cenário cultural de Porto Alegre, a "caríssima" Banda Municipal ocupava um espaço privilegiado, embora sempre fosse lembrado o alto custo de sua manutenção. Suas apresentações, realizadas inicialmente na Praça da Alfândega, foram transferidas para a Praça da Matriz ainda no ano de sua estreia, 1926, e, no ano seguinte, ela se instalou na praça de concertos Araújo Vianna. Para o cronista, a função educativa desempenhada pelo conjunto justificava sua existência, já que ele seria capaz de educar os sentimentos da população, desde que mantida sua opção pelo repertório clássico. "A Banda é, de fato, um presente régio do município, faz gosto ouvi-la, pela sua beleza de conjunto, pela magnífica escolha de seus programas de execução e pelo cunho altamente artístico que lhe foi dado" (11 jul. 1926). Em um período em que o jazz não havia sido ainda nobilitado, e adquirido o status de música de qualidade, era decerto de se esperar que Callage o definisse como "pancadaria desordenada" 
(11 ago. 1927). Neste e em outros assuntos, como, por exemplo, a vida teatral em que o cronista condenava as "revistas" e "o gênero nacional, com sal, pimenta, e pó de mico por cima" -, ele se alinha à cultura de elite e atribui à coluna, tanto quanto à Banda, uma função pedagógica de difusão da arte de "bom gosto" (10 jan. 1929).

A sociabilidade urbana de Porto Alegre, na década de 1920, era também alimentada pelo espaço, meio público, meio privado, dos cafés, espécie de continuidade da rua, onde, frequentemente, o cronista recolhe matéria para a coluna. A popularidade dos cafés não era, é claro, um fenômeno exclusivo de Porto Alegre ou mesmo da tardia modernidade brasileira, uma vez que os cafés e pubs (apócope de public houses) foram, no Antigo Regime, um espaço fundamental para o intercâmbio de ideias e o debate em torno dos principais problemas públicos. A bebida - café, chá ou chocolate - era, então, apenas um pretexto para o encontro na "sociedade das cafeteiras", que surge, nas grandes cidades europeias e norte-americanas, entre 1680 e 1730, em um contexto de ampliação do espaço urbano, imigrações e intensificação do comércio ${ }^{4}$. Os temas em debate eram, exclusivamente, os de interesse público, sobretudo a política, que alimentava as polêmicas em torno dos rumos da sociedade civil e, por isto, fazia parte do ethos do café o diálogo entre desconhecidos e a indistinção entre seus participantes. Muitos jornais foram criados nas cafeterias, ali escritos e lidos em voz alta, e, como eles, os cafés também participaram da formação da opinião pública e da difusão de um estilo próprio de comunicação (Chrislieb, 2004, p. 21-26).

A criação de uma opinião pública atuante era, certamente, um dos objetivos da crônica de $A$ Cidade, que se queria não apenas um retrato da vida urbana de Porto Alegre, mas um agente de sua transformação. Leve-se em conta que se vivia, então, um período de grandes mudanças no espaço urbano, o que se somava a uma elevada 
expectativa de conversão da capital em uma verdadeira metrópole (Monteiro, 1995). A coluna era um espaço polifônico em que o cronista - que nunca abriu mão de difundir suas opiniões, mesmo as mais polêmicas e pessoais - dialogava com seus leitores -, que também tinham espaço cativo, através da publicação de suas cartas - e com os agentes do poder público. Estes últimos, destinatários preferenciais da crítica jornalística, também tinham espaço para defender-se, embora esta não fosse uma prática usual.

Em várias crônicas, o café é um equivalente da rua, espaço privilegiado para o encontro e o diálogo. Por vezes, as vozes "reproduzidas" pelo cronista pertencem a personagens célebres no meio intelectual e artístico da cidade. Mais comumente, entretanto, as conversas narradas dão-se entre desconhecidos, e ingressam no espaço textual através do recurso da "reportagem", ou seja, a casual anotação fiel de diálogos que teriam, de fato, sido ouvidos pelo jornalista. Este recurso possibilitava expor o que seria a "opinião pública", diversificar a linguagem da crônica, apelando ao discurso direto e superar a limitação temática - já que a proposta da coluna era discutir apenas assuntos urbanos restritos a Porto Alegre.

Esta virtude essencialmente participativa da coluna repetia uma característica da sociabilidade dos cafés, o relativo anonimato de seus participantes, que não podiam se arrogar o direito de não serem incomodados: "Estivesse quem estivesse ao seu lado, conhecido ou desconhecido, ele não perdia vasa, vinha à tona o seu tempo predileto, o assunto único que girava os seus nervos, que desemperrava a sua língua - a revolução". Apelidado, ironicamente, de "revolucionário do café", o jovem, então citado, acabou, de fato, engrossando as filas dos voluntários que foram à Revolução de 1930 (09 nov. 1930). Compreende-se, assim, que o café seja metaforizado em A Cidade como "coxilha", em referência ao passado bélico do estado e ao paralelismo entre o debate e a ação. 
É por intermédio desses cafés, desses vários centros de reunião pública, espalhados nos principais pontos de movimento da cidade, que o porto-alegrense cumpre o seu destino. Toma o seu café e dá o seu dedo de prosa. Passam por esses salões vivamente animados todos os acontecimentos do dia e onde se forjam todos os boatos do mais verossimil ao mais extravagante. Como é natural, são neles, ainda, que costumamos nos reunir para cortar da vida alheia... Quem vai a esses centros para tomar a rubiácea do Sr. Júlio Prestes encontra rodas que satisfazem todos os paladares. Temos ali as rodas dos políticos, dos desportistas, dos intelectuais das duas espécies (passadistas e modernistas), dos boateiros-morais e até mesmo dos derrotistas da grande causa em que estamos hoje, todos nós, do Rio Grande, patrioticamente empenhados."

(20 out. 1929)

De fato, a partir da campanha de Getúlio Vargas à presidência da República, as crônicas políticas de Callage tornam-se mais frequentes. As referências aos debates, então, travados nas conversas das rodas reunidas nos cafés e nas ruas desempenhavam a função de trazer ao conhecimento do leitor as polêmicas em voga, desmentir boatos, comentar as notícias e, sem dúvida, veicular as opiniões do próprio cronista, sem que estas soassem como opiniões pessoais. Afinal, pelo compartilhamento de mesas e balcões, pelo baixo preço da bebida, pelo entra e sai constante, que garantia o fluxo de informações, pela publicização das ideias, pelo gosto da polêmica, o café era, como $A$ Cidade, um espaço político por natureza, o que implicava em uma dose considerável de comprometimento com a coisa pública. 


\section{O futebol e os subúrbios}

Embora as predileções do cronista o alinhassem às plateias eruditas, as crônicas de A Cidade demonstram o entusiasmo geral despertado pelo futebol, já bastante difundido entre amplas camadas da população. Entretanto, a paixão pelo esporte podia dar margem a excessos, como os matches improvisados pelas ruas da cidade. Para o colunista, embora o esporte cumprisse a importante função social de fortalecer os organismos depauperados, preparando-os para o trabalho, observava-se nas ruas exatamente o contrário: nas vias públicas, o futebol era uma atividade socialmente improdutiva e mesmo prejudicial, pois colocava em risco as vidraças e a integridade física das famílias, além de favorecer a ofensa à moral pública.

Já não tem conta o número de vezes que temos reclamado contra o futebol nas ruas, contra os danos causados pelo mesmo, contra a madraçaria e a vagabundagem que ele congrega nesses ajuntamentos da via pública. Para o caso, já chamamos até a atenção da polícia, solicitando a sua intervenção, no sentido de acabar com esses ajuntamentos perniciosos, onde o baixo calão campeia em contínuas ofensas à moral."

(05 fev. 1927)

O esporte organizado, entretanto, tinha em Callage um grande entusiasta e as crônicas sobre o futebol deixam-se contaminar inteiramente pela atmosfera de frenesi que ele inspirava. Reportando o vazio da cidade, em função da presença maciça dos torcedores nos campos, o cronista refere com admiração o "entusiasmo que ele patrioticamente desperta na alma das multidões", registrando a expectativa gerada 
pela participação do selecionado sul-rio-grandense no Campeonato Brasileiro de Futebol de 1925 (23 jul. 1925). No ano seguinte, o grupo chegou à grande final contra a delegação de São Paulo, e, mais uma vez, Callage reportou o fervor religioso do "culto desportivo" com que a população acorria aos painéis dos jornais, em busca das notícias que chegavam via telégrafo e ali eram divulgadas para a torcida "vibrante, harmônica, inânime" (12 out. 1926).

As temporadas futebolísticas possuíam uma força arrebatadora: “Lá está a população inteira nos gramados, os que podem gozam o cômodo mais ou menos suave das arquibancadas; os que não podem espiam pelas frestas das cercas, se debruçam pelos muros, ou trepam nas árvores adjacentes [...]" (23 jul. 1925)5. Em 1927, A Cidade registrou uma vitória da seleção gaúcha em jogo do Campeonato Brasileiro, o que conduzira o povo extasiado a procurar os espaços públicos:

O povo inteiro, mesmo os menos afeitos à torcida, vibrou com a notícia do resultado, que durante a tarde era de momento a momento anunciado pelos jornais. Sentia-se perfeitamente esse grato prazer da vitória estampado em todos os rostos, em todas as fisionomias. Não houve cara severa e ríspida de burguês indiferente que não se amaciasse com a nota vibrante logo espalhada pelos quatro cantos da urbs. E muito mais que nos domingos anteriores, já pelo resultado dessa conquista, já pela rara beleza da tarde e da noite, o movimento de passeantes domingueiros foi deveras extraordinário. Em toda parte acudia o povo em massa: à frente dos jornais na Praça, à hora da retreta da Banda Municipal, nos cinemas, nos teatros, nos cafés, etc., premia-se uma multidão desusada."

(25 out. 1927) 
Enquanto a região central da cidade fornecia os principais atrativos mundanos, os subúrbios eram populares atrações familiares. Com a expansão da malha urbana, surgem novos bairros e, consequentemente, novas oportunidades de lazer, pois os ditos "arrabaldes" não apenas atraíam moradores, mas também visitantes de domingo. Nos anos 1920, intensifica-se a ocupação de áreas fora do centro pela população mais abastada da capital, em busca de terrenos mais altos e mais saneados, a partir das ruas Duque de Caxias e Independência, em direção ao que se tornaria o bairro Moinhos de Vento. Este movimento foi também incentivado pela construção da Praça Júlio de Castilhos e da Nova Hidráulica do município, inaugurada em 1928, além da ampliação das linhas de bondes elétricos, sistema instalado na cidade, a partir de 1908. Desde 1926, o transporte em ônibus passava a atender parte significativa da demanda e a viabilizar a ocupação de terrenos em loteamentos nas regiões não atendidas pelos bondes (Monteiro, 2004, p. 55).

No caso do Moinhos de Vento, o cronista testemunhava o contraste entre a feição aristocrática que o bairro possuía, desde a abertura de suas primeiras ruas, e a inexistência de uma infraestrutura urbana condizente com a prosperidade de seus proprietários, uma vez que faltava, ainda, em 1925, policiamento e iluminação (08 ago. 1925). O mesmo se observa no bairro Mont'Serrat, cuja expansão é observada meses depois (29 jun. 1927). Em 1930, era anotada a grande melhoria na organização do Moinhos de Vento, que já contava com calçamento e luz elétrica, ainda que, segundo o colunista, a excelência do bairro devesse ser atribuída à iniciativa privada.

Naquele momento, era ainda aguardada a realização, pela Intendência, do grande projeto que havia sido proposto por Callage, no primeiro ano da coluna: a construção de um jardim de inverno e um belvedere no morro Ricaldone ${ }^{6}$, ou seja, um mirante localizado no topo de uma colina com vista para o Rio Guaíba, que seria um novo espaço de lazer na cidade (28 jun. 1930). Este projeto nunca foi realizado. Enquanto 
isto, a precária manutenção e a insegurança condenavam ao abandono o belvedere construído entre as ruas Duque de Caxias e Coronel Fernando Machado (23 maio 1929).

Higienópolis, Rio Branco e Santa Teresa eram também representativos da expansão do povoamento da cidade, para além dos limites habituais. O mais novo desses bairros era Petrópolis, composto na época por "infinidade de casas pequenas e modestas moradas que ali começam a se erguer rapidamente", sendo os terrenos "vendidos em prestações, a preços ínfimos", marcando o crescimento da cidade na direção da então chamada Estrada do Caminho do Meio, na altura da atual Avenida Protásio Alves. Bucolismo e civilização são os dois polos em que se divide a descrição dos arrabaldes:

[Petrópolis] é o mais novo bairro de Porto Alegre. Surgiu de improviso, da noite para o dia, como uma consequência natural do desenvolvimento da área da capital. Ela, que tinha até bem pouco tempo uma raia limitadíssima, espraia-se, hoje, vertiginosamente, para além de Teresópolis e da Glória, para além de São João e de Navegantes, para além de Partenon e Mont'Serrat, povoando toda a faixa do Guaíba que vai da Praia de Belas até a enseada estonteante de Pedra Redonda, que Porto Alegre transformou num retiro maravilhoso de preguiça e de amor, ponto de atração irresistível do nosso ócio domingueiro nas tardes ardentes de verão. É a cidade que caminha, é a cidade que marcha vi toriosa para a frente, espraiando-se, alongando-se, numa ânsia febril de civilização."

(16 out. 1927) 
Apesar do péssimo estado da estrada que conduzia até o bairro, existia já um serviço de ônibus que o colocava ao alcance da população, e, em seus primeiros meses de existência, Petrópolis havia se tornado um subúrbio atraente para o lazer do portoalegrense, atraído pela beleza natural e pela diversidade de seus panoramas (04 nov. 1927). O fascínio da paisagem suburbana era também exercido pela Vila Nova, espécie de reminiscência da vida rural, "um ponto propício aos idílios amorosos, aos passeios, às festas, aos piqueniques e aos ócios domingueiros dos que fogem da cidade para a alegria da existência agreste" (11 nov. 1927). O lazer da população citadina estava ainda, como se observa, muito ligado à possibilidade de fuga do ambiente urbano, em busca de um provisório "retorno" à vivência da natureza e da vida rural.

Nos limites do município, as praias fluviais tornavam-se o cenário privilegiado da vida de Porto Alegre, durante o verão. Para os mais afortunados, e, mesmo para a classe média, a viagem de veraneio em direção à serra, à praia ou ao campo, oferecia ar fresco e o prazer do contato com a natureza, num período que se estendia de dezembro a março. A fuga para o veraneio fazia com que a cidade parecesse esvaziada, ainda que, de acordo com os cálculos de Callage, o número de veranistas estivesse por volta de dois mil - cerca de 1\% do total de seus habitantes (04 mar. 1927). É que, desprovida do bulício das ruas, a vida no verão de Porto Alegre tornava-se ainda mais torturante para aqueles que ficavam, especialmente porque rareavam dois dos seus tipos mais significativos, responsáveis pelo movimento e pela graça de suas ruas: os estudantes e as mulheres requintadas. O retorno das férias de verão era, compreensivelmente, aguardado com ansiedade pelo cronista, observador assíduo da circulação em torno do comércio central.

Com Michel de Certeau, podemos ver a cidade como um agregado de errâncias que se cruzam na busca de um lugar próprio, múltiplos deslocamentos que constroem um espaço relacional, mas não um lugar, aquilo que se busca e com o qual se sonha 
(CERTEAU, 2009, p. 169). A experiência coletiva da cidade é incapaz de nos fornecer uma identidade além do simbolismo de seu nome, espelhado no pequeno espaço de jornal que desenha, entre tantos outros, um percurso pelas ruas, entre cenários e personagens, à procura de um lugar. A rua oferecia, assim, o espetáculo de seu ritmo intenso de intercâmbio material e simbólico, acompanhado diariamente por A Cidade. A crônica urbana, reportagem pessoal desta experiência coletiva, divide-se entre a literatura e o jornalismo, inscrevendo-se nos circuitos de uma rotina em que o sublime divide espaço com o abjeto, e, a futilidade de um mundo de seduções de consumo com a profundidade do debate em torno das grandes questões públicas. A coluna de Roque Callage no Diário de Notícias metaforiza as vias centrais, as ruelas dos arrabaldes, as praias do Guaíba, as praças e mesmo espaços semipúblicos, como os campos de futebol e os cafés. Promovendo um diálogo contínuo entre texto e experiência, A Cidade participava, assim, decisivamente, da construção de um sentido de comunidade, que fazia de Porto Alegre uma pequena metrópole vivida e sonhada coletiva e cotidianamente.

\section{REFERÊNCIAS}

A CIDADE. Diário de Notícias, Porto Alegre, ano III, n. 293, p. 3, 07 fev. 1928.

ANDERSON, Benedict. Comunidades imaginadas: reflexões sobre a origem e a difusão do nacionalismo. São Paulo: Companhia das Letras 2008.

BENJAMIN, Walter. O narrador. Considerações sobre a obra de Nikolai Leskov. In: arte e política. Ensaios sobre literatura e história da cultura. São Paulo: Brasiliense, 2012. pp. $213-240$.

Magia e técnica, . Passagens. Belo Horizonte: Editora UFMG; São Paulo: Imprensa Oficial do Estado de São Paulo, 2009.

BRUM, Rosemary Fritsch. Caderno de pesquisa: notícias de imigrantes italianos em Porto Alegre, entre 1911 e 1937. São Luiz: Edufma, 2009.

CALlAGE, Roque. A Cidade. Diário de Notícias, Porto Alegre, ano I, n. 46, p. 3, 24 abr. 1925. . A Cidade. Diário de Notícias, Porto Alegre, ano I, n. 99, p. 3, 25 jun. 1925. 
CALlAGE, Roque. A Cidade. Diário de Notícias, Porto Alegre, ano I, n. 123, p. 3, 23 jul. 1925. . A Cidade. Diário de Notícias, Porto Alegre, ano I, n. 124, p. 3, 24 jul. 1925. . A Cidade. Diário de Notícias, Porto Alegre, ano I, n. 138, p. 3, 08 ago. 1925. . A Cidade. Diário de Notícias, Porto Alegre, ano I, n. 141, p. 3, 12 ago. 1925. . A Cidade. Diário de Notícias, Porto Alegre, ano I, n. 214, p. 3, 05 nov. 1925. . A Cidade. Diário de Notícias, Porto Alegre, ano I, n. 219, p. 3, 11 nov. 1925. . A Cidade. Diário de Notícias, Porto Alegre, ano I, n. 226, p. 3, 19 nov. 1925. . A Cidade. Diário de Notícias, Porto Alegre, ano I, n. 246, p. 3, 12 dez. 1925. . A Cidade. Diário de Notícias, Porto Alegre, ano II, n. 18, p. 3, 21 mar. 1926. . A Cidade. Diário de Notícias, Porto Alegre, ano II, n. 114, p. 3, 11 jul. 1926. . A Cidade. Diário de Notícias, Porto Alegre, ano II, n. 192, p. 3, 10 out. 1926. . A Cidade. Diário de Notícias, Porto Alegre, ano II, n. 193, p. 3, 12 out. 1926. . A Cidade. Diário de Notícias, Porto Alegre, ano III, n. 294, p. 3, 05 fev. 1927. . A Cidade. Diário de Notícias, Porto Alegre, ano III, n. 3, p. 3, 04 mar. 1927. . A Cidade. Diário de Notícias, Porto Alegre, ano III, n. 60, p. 3, 11 maio 1927. . A Cidade. Diário de Notícias, Porto Alegre, ano III, n. 102, p. 3, 29 jun. 1927. . A Cidade. Diário de Notícias, Porto Alegre, ano III, n. 117, p. 3, 16 jul. 1927. . A Cidade. Diário de Notícias, Porto Alegre, ano III, n. 139, p. 3, 11 ago. 1927. . A Cidade. Diário de Notícias, Porto Alegre, ano III, n. 143, p. 3, 16 ago. 1927. . A Cidade. Diário de Notícias, Porto Alegre, ano III, n. 152, p. 3, 26 ago. 1927. . A Cidade. Diário de Notícias, Porto Alegre, ano III, n. 203, p. 5, 25 out. 1927. . A Cidade. Diário de Notícias, Porto Alegre, ano III, n. 211, p. 5, 04 nov. 1927. . A Cidade. Diário de Notícias, Porto Alegre, ano III, n. 218, p. 5, 11 nov. 1927. . A Cidade. Diário de Notícias, Porto Alegre, ano III, n. 224, p. 3, 18 nov. 1927. . A Cidade. Diário de Notícias, Porto Alegre, ano III, n. 268, p. 3, 08 jan. 1928. . A Cidade. Diário de Notícias, Porto Alegre, ano IV, n. 112, p. 3, 11 jul. 1928. . A Cidade. Diário de Notícias, Porto Alegre, ano IV, n. 223, p. 3, 18 nov. 1928. 
CALlAGE, Roque. A Cidade. Diário de Notícias, Porto Alegre, ano IV, n. 251, p. 3, 21 dez. 1928.

. A Cidade. Diário de Notícias, Porto Alegre, ano IV, n. 261, p. 3, 04 jan. 1929.

. A Cidade. Diário de Notícias, Porto Alegre, ano V, n. 71, p. 3, 23 maio 1929.

. A Cidade. Diário de Notícias, Porto Alegre, ano V, n. 200, p. 5, 20 out. 1929.

. A Cidade. Diário de Notícias, Porto Alegre, ano V, n. 227, p. 5, 22 nov. 1929.

. A Cidade. Diário de Notícias, Porto Alegre, ano V, n. 235, p. 5, 01 dez. 1929.

. A Cidade. Diário de Notícias, Porto Alegre, ano V, n. 266, p. 5, 11 jan. 1930.

. A Cidade. Diário de Notícias, Porto Alegre, ano V, n. 102, p. 5, 28 jun. 1930.

. A Cidade. Diário de Notícias, Porto Alegre, ano V, n. 189, p. 5, 09 out. 1930.

. A Cidade. Diário de Notícias, Porto Alegre, ano V, n. 217, p. 5, 09 nov. 1930.

1925.

. A "la garçonne". Chronica de idéas curtas. Diário de Notícias, Porto Alegre, ano I, n. 1, p. 3, 01 mar.

CERTEAU, Michel de. A invenção do cotidiano. Vol. 1: Artes de fazer. Petrópolis: Vozes, 2009.

CHRISTLIEB, Pablo Fernándes. El espíritu de la calle. Psicologia política da cultura cotidiana. Rubí (Barcelona): Anthropos; México: Universidad de Querétano, 2004.

MONTEIRO, Charles. Porto Alegre no século XX: crescimento urbano e mudanças sociais. In: DORNELLES, Beatriz (Org.). Porto Alegre em destaque: história e cultura. Porto Alegre: Edipucrs, 2004. pp. 51-74.

. Porto Alegre: urbanização e modernidade. A construção social do espaço urbano. Porto Alegre: Edipucrs, 1995.

PESAVENTO, Sandra Jatahy. O imaginário da cidade. Visões literárias do urbano. Paris. Rio de Janeiro. Porto Alegre. Porto Alegre: Ed. Universidade da UFRGS, 2002.

SARLO, Beatriz. Modernidade periférica. Buenos Aires 1920 e 1930. São Paulo: Cosac Naif, 2010.

SENNET, Richard. O declínio do homem público. As tiranias da intimidade. São Paulo: Companhia das Letras, 1988.

SEVCENKO, Nicolau. Orfeu extático na metrópole. São Paulo sociedade e cultura nos frementes anos 20. São Paulo: Companhia das Letras, 1992.

STEYER, Fábio Augusto. Cinema, imprensa e sociedade em Porto Alegre (1896-1930). Porto Alegre: Edipucrs, 2001. 


\section{NOTAS}

1 No período em que Roque Callage era o redator da coluna, suas crônicas traziam a assinatura "C.". As crônicas ocasionalmente não escritas por ele não eram assinadas.

2 As crônicas de $A$ Cidade serão a partir daqui indicadas apenas pela data de sua publicação. Todas as citações literais terão sua ortografia atualizada.

3 Na definição de Karl Marx, em O Capital: "o valor de cada mercadoria é determinado pela quantidade de trabalho materializado em seu valor de uso, pelo tempo de trabalho socialmente necessário à sua produção" (Benjamin, 2009, p. 490).

4 No caso brasileiro, o fenômeno era, no entanto, relativamente recente. Como registra Sandra Pesavento, a partir das crônicas de Aquiles Porto Alegre, na década de 1870, os cafés eram lugares malvistos na cidade. Na verdade, naquele contexto havia apenas um café em Porto Alegre, o Café da Fama (Pesavento, 2002, p. 296).

5 O futebol sul-rio-grandense já se alimentava, na segunda metade dos anos 1920, da rivalidade entre o Grêmio Futebol Porto-alegrense o Sport Clube Internacional.

6 O nome faz referência ao pneumologista italiano José Ricaldone, proprietário de um extenso terreno no bairro e de um palacete em estilo renascentista italiano, localizado na Rua Santo Inácio (Brum, 2009).

Recebido em: 30 ago. 2013

Aceito em: 08 mar. 2014

\section{Endereço do autor:}

Luciana Murari <lmurari@hotmail.com>

Universidade de Caxias do Sul

Programa de Pós-graduação em Letras, Cultura e Regionalidade

Rua Francisco Getúlio Vargas, 1130, Bloco L, Sala 207 - Petrópolis

95070-560 Caxias do Sul, RS, Brasil 